\title{
Perceptions of the EfFEcts of a Constructivist Classroom Approach on Academic Service- LEARNING: AN EXPLORATORY STUDY
}

\author{
Lisa M. Walters
}

Lisa M. Walters, Assistant Professor of Operations Management, Fredonia State University of New York, E336 Thompson Hall, Fredonia, NY 14063, 716-673-3505, Lisa.Walters@Fredonia.edu

\begin{abstract}
This exploratory study sought to understand the perceptions of students and a community-client when an academic service-learning project was introduced into a capstone strategic management course using a constructivist pedagogy. Surveys were administered to the students in the course as well as to the community-client. The student surveys provided an understanding of the extent to which the students perceived the academic service-learning project as valuable to the community and the academic service-learning approach as a valuable instructional method, while community-client survey provided an understanding of the extent to which the community-client perceived the academic service-learning project as valuable. The results of the study suggest that the use of the
\end{abstract}


constructivist classroom in conjunction with academic service-learning supports students' positive perceptions of the value of the service-learning project to the community and as an instructional method. The results also suggest that the simultaneous use of these two approaches provides a product perceived as valuable to the community client.

Keywords: Academic service-learning; Strategic management; Constructivist classroom

\section{INTRODUCTION}

The mission of the Fredonia State University of New York's Department of Business Administration is to integrate excellence in instruction, faculty scholarship, and proactive community service to prepare students from diverse backgrounds to be successful, ethical, and globally-aware business professionals. In support of this mission, the curriculum in the Business School's majors of accounting, economics, finance, management, and marketing includes strong components in critical thinking, oral and written communication, ethics, leadership, and international awareness. The capstone course, Strategic Management, is specifically aligned to the University's baccalaureate goals that students will be skilled, connected, creative, and responsible. The challenge, from a professor's perspective, is to design curriculum that supports the department's mission and, thus, further supports these baccalaureate goals, while maintaining the enthusiasm of the students.

The union of two pedagogical tools may provide a curriculum that achieves the mission of the Department of Business Administration. One tool is academic service-learning (also known as community servicelearning or simply service-learning), and the other is constructivist learning. 


\section{LiterATURE REVIEW}

To better understand how these two pedagogical tools interact, it is important to understand each in its own regard. To this end, the literature review includes research on the constructivist approach to teaching followed by the research on academic service-learning.

\section{The Constructivist Classroom}

Constructivism is based on the notion that people form mental models that are used to understand their worlds (Alesandrini \& Larson, 2002). These models are constructed from the individual's existing (or prior) knowledge (Lattuca, 2006). As applied to the classroom, constructivist pedagogy provides a means for students to dynamically experience new ideas, with an emphasis on active learning in which the learner "discusses, questions, debates, hypothesizes, investigates, and argues" (Lattuca, 2006, p. 355) as a means to understand new information. This learning is mediated not only by the instructor, who can guide students in the development of new knowledge and skills, but also by peers, when they share understandings of an assignment both inside and outside the classroom.

As noted, an assumption of constructivism is that all students have knowledge and beliefs that form the basis for their understandings of the world. These beliefs must be brought to the surface, reflected on, examined, and then discarded or elaborated and refined. To this end, the instructor needs to ensure that students have access to the resources, tools, and information needed for tasks in a variety of subject areas. In this way, teaching becomes the "act of designing experiences that encourage and enable learning” (Lattuca, 2006, p. 356), both inside and outside the classroom.

As noted by Milbrandt, Felts, Richards, and Abghari (2004), because knowledge is acquired both inside and outside the classroom, students need to develop certain cognitive structures that accommodate and assimilate new knowledge into previously acquired knowledge. To help 
students to develop these structures, teachers must determine the depth of students' knowledge, design appropriate learning experiences for groups of students, assist students in the learning and practicing of new knowledge and skills, evaluate student learning, and provide students with feedback that will encourage further learning. Although Milbrandt et al. focus on the constructivist approach to art education, they offer guidelines that can be applied to other subject areas:

- Provide students with a variety of tools for research so students become the primary research investigators

- Frame strategies for several large and small group collaborations to foster peer support and interaction

- Develop a flexible classroom climate that encourages student inquiry and discussion

- Present numerous opportunities throughout the lesson for students to make individual choices.

- Negotiate lesson objectives and evaluation criteria with students

- Encourage students to create real world and cross-disciplinary connections that extend beyond the classroom

- Act as a participant facilitator in the teaching-learning process

- Encourage students to take ownership of their learning, develop expertise, and share their knowledge with others. (p. 33)

While Lattuca (2006) and Milbrandt et al. (2004) provide an understanding of the fundamentals of constructivism and constructivist pedagogy, Travis and Lord (2004) demonstrate its effectiveness. The authors compared two groups of undergraduate nonscience majors in a biology lab, for which one group was taught in a traditional teacher-centered style, while the other was taught as a constructivist class. Travis and Lord explained that the teacher-centered approach assumes that all students have the same level of background knowledge of the subject matter and are able to learn at the same pace. Further, in terms of lab activities, this approach does not encourage discussion or exploration of the relevant concepts. In constructivist or student-centered learning, in contrast, 
teachers assist students to develop insights and make connections with prior knowledge and then leave the discussion and discovery process up to the student groups. Such learning involves the posing of questions to students who work together in small groups to develop solutions. Through the process of explaining their ideas and solutions to the other students in the group, and then to the entire class, students can come to an understanding of the concepts being introduced.

Travis and Lord (2004) took several measure of both the traditionallyand constructivist-taught groups, which includes scores on a quiz and on the Science Attitude Inventory, attendance, and relevant behaviors, e.g., student interaction, participation, time spent off-task. The results indicated that students in the constructivist group had higher quiz scores, a greater appreciation of science, better attendance, and more participation in lab activities than did students in the traditionally-taught group. Students in the constructivist group stated that they "enjoyed coming to lab because they were able to interact with members of the team, making lab more interesting" (p. 16) and that "the hands-on work with other students and the open discussion of the lab material" were valuable aspects of the process (p. 17).

\section{Academic Service-Learning}

According to Bush-Bacelis (1998), academic service-learning as "a method by which students learn and develop through active participation in thoughtfully organized experiences that meet actual community needs and are coordinated with the academic and local communities" (p. 20). Academic service-learning has its roots in the 19th century, most notably with the work of John Dewey (1897). Dewey believed that education is an individual's participation in the community's social fabric and that education should reflect the needs of society. He viewed the teacher as a member of the community, whose role is to assist students in their learning, and felt that the method of teaching should focus on the interests of the students, which would results in active learning. 
Dewey (1938) believed that a balance between traditional and progressive education is needed. He felt that traditional education was too rigid but that progressive education could be too impulsive or unconstrained. He recommended that, to provide such a balance, education must provide some degree of educationally valuable experience. To Dewey, a quality educational experience allows for continuity, that is, the leaning outcomes of the experience can be carried forward by the learner and can shape future experiences of the learner.

Kolb (1984) provided a four-stage experiential learning cycle that embraces Dewey's experience imperative. The four components of Kolb's cycle are concrete experience, reflective observation, abstract conceptualization, and active experimentation. Kolb identified the need for experience within the first and fourth stages, which suggests the continuity of the experience, as identified by Dewey. Specifically, after a quality experience in the first stage, one processes and learns from the experience during the second and third stages; this is followed by a carrying forward of the learning in the fourth stage.

Both Dewey (1938) and Kolb (1984) view experience as a fundamental attribute of learning. Dewey, in particular, can be seen as encouraging an academic service-learning approach, specifically in terms of his belief that education should reflect the needs of society. In this regard, there is a substantial body of literature on academic service-learning.

One approach to academic service-learning is found in the research of Bush-Bacelis (1998), who outlined an academic service-learning approach to teaching business communication. In their course, teams of students select a non-profit organization with which they wish to work. They work with the non-profit to determine to determine the needs to be addressed by the project and then provide deliverables, which include typical business communications. For example, the academic servicelearning projects include a written and oral version of the proposal for work, progress report, and final report. The written proposal takes the form of a letter addressed to the contact person from the organization 
chosen for the project, while, the oral proposal, which is presented to the class, consists of a brief presentation of the proposal, including the reasons for selecting the organization and the students' experiences with contacting the organization. As part of the presentation, students ask for input from the class in regard to strategies and resources.

Halfway through the term, students update their progress in a written progress report, which is submitted as a memo to the professor, as well as through an oral progress report made to the class. The written final report contains a summary of the project, including documentation of completed tasks, and a reflection on how the project ties into what was learned in class. The oral final report is a formal presentation in which students revisit the project's beginning, discuss the process, and then display their final product.

Bush-Bacelis (1998) believes that the most important variable for the success of the academic service-learning project is the approach that the professor uses to present the idea to the students. The professor must present the project in a positive, organized manner, explain the benefits for the student, and emphasize students' degree of autonomy in undertaking this project. Bush-Bacelis concluded that the greatest benefit for students is that "they are able to connect the readings, class discussions, and other assignments with the real world, full of real people, with real problems that students try to help solve" (p. 27). She believes that, if properly developed and conducted, academic service-learning helps students to understand abstract concepts and to apply them to an organization.

Papamarcos (2002), while sharing the belief that an understanding of abstract concepts results from academic service-learning, also believes that the benefits to the student are broader and include the enhancement of students' skill levels, academic performance, social responsibility, personal and value development, self-efficacy, and related constructs. His belief provides a foundation for the business education servicelearning projects at St. John's University in New York City. Papamarcos 
explained that, in the team-based, service-learning course, students learn theoretical concepts associated with a topic, subsequently cultivating those concepts into refined actions through team communications and organizational interfaces, thereby enhancing critical and creative thinking. These activities enhance the students' ability to better compete in the job market.

Papamarcos (2002), however, moved away from the focus on student benefits and toward the benefits for the organization and the community. He introduced the notion of "new" service-learning, which has a focus on "structural objectives" or engagements that continue to serve after the semester (and the project) has ended. He presented three projects, illustrative of the "new" service-learning and then discussed their critical success factors, which included project, people, and process considerations. Project considerations include the fit between a project and the course objectives as well as an identifiable beginning and end, with clear boundaries in regard to scope. People considerations encompass student, client, and faculty qualifications. Students must be able to address the uncertainty of a difficult project and, as such, must have excellent technical, interpersonal, and communication skills and be creative and critical thinkers. Clients must have a sense of the importance of the project and a commitment to its success. Faculty must have a high level of commitment to service-learning, in general, and to the project, in particular. Finally, in regard to process, Papamarcos noted that the use of certain procedures for clarifying the dimensions of the project, recruiting and selecting student volunteers, tracking progress, and making needed adjustments, will help ensure the project's success.

Upon completion of the project, students make a formal presentation of the final work product to representatives of the client organization, who are invited to the campus. The project is then graded by the professors, the client organization, and the students, who grade one another, based on the following criteria: (a) the achievement of the overarching objectives, (b) the resourcefulness or creativity of the team, (c) the extent to which team 
members worked together, (d) whether students "gave it their all", and (e) whether the final work product approximated professional standards and, if not, whether the failure was understandable (Papamarcos, 2002).

In keeping with Papamarcos, Barr (2010) believes that civic responsibility and service-learning are inextricably intertwined and that servicelearning has an impact on the academic and life skills development of undergraduate students and, ultimately, on their career preparedness. She presented the structure and evolution of a marketing research course that incorporates service-learning and provides a framework for empirical research designed to evaluate the effectiveness of service-learning in such a course.

The primary objective of the course is to have students apply the theories and techniques learned in the course, through the lectures and textbook, to an original marketing study in a service-learning setting. The secondary objectives included the opportunity to conduct web-based research, participate in teamwork, and develop written and oral communication skills. The service-learning project consists of three phases. The first phase includes the introduction, secondary, and exploratory research as well as the development of a conceptual framework and propositions. The second phase concerns the methodology, including operationalization of variables, questionnaire design, research design, and sample selection. The third phase comprises data collection, statistical analysis, presentation of findings and conclusions, acknowledgment of study limitations, and recommendations for future research. The teams also are required to deliver an oral report (Barr, 2010).

Similarly to Barr, Buff (2011) recognized the value of academic servicelearning in courses with an analytic component. Buff described two problem-based service-learning (another term for academic servicelearning) projects that were integrated into two sections of consumer behavior courses. The projects were designed to benefit a women's group in Kenya and a New York State county fair, both of which were nonprofit organizations. The aim of the projects was to help to achieve the following 
outcomes: (a) apply understanding of consumer analysis and marketing strategy; (b) further develop analytical and communication skills; and (c) further develop group interaction skills. Students were provided with a syllabus that outlined the assignments on a weekly basis. The project tasks were the same for both projects and involved developing a situational analysis, marketing plan, and marketing communications and then meeting with the instructor to review progress. Upon completion of the project, students were given a reflection assignment, for which they were asked for their "honest and candid feedback about the group project" (p. 128).

The results indicated that the PBSL project took more time to design, develop, and implement than did other projects used in the past; however, this result was expected. However, the project allowed for the application and integration of concepts, and students achieved the learning outcomes of the course. Buff (2011) concluded that "the challenges associated with PBSL do not outweigh the benefits of service learning to the student, especially a student attending a college with a service and/or values oriented mission statement” (pp. 129-130).

Simons and Cleary (2005) used an explanatory mixed-methods design to evaluate the effects of a service-learning model on the academic learning, personal and interpersonal development, and community engagement of 59 service-learning students, enrolled in two sections of an educational psychology course at a private teaching university in an eastern metropolitan area during spring 2003. A self-report survey was used to collect data on students' gender, race, age, year in school, and volunteer experience. They also developed a 52-item questionnaire to gather data on students' performances at the placement sites; assessed learning outcomes through students' scores on examinations, essays, and midterm and final course grades; and developed eight open-ended reflection questions about students' service-learning experiences.

Both quantitative and qualitative data were collected before, during, and after service. As noted, Simons and Cleary (2005) used an explanatory 
mixed-method design, which uses a sequential phase of quantitative and qualitative data collection, and an integrative analysis, whereby quantitative findings provide a context for the qualitative results. The analysis resulted in four major themes: Service-learning fosters identification with community recipients, enhances academic learning, enhances career decisions, and shapes students perceptions of the self and the community. Once the themes were identified, axial coding was conducted to explain how students learned while engaged in service-learning.

The results demonstrated that participation in service-learning affects service-learning, personal and interpersonal development, and community engagement. The findings for academic learning, however, were mixed. Service-learners earned better grades on the second written exam than on the first and third, which demonstrates only partial gains. The findings in regard to personal and interpersonal development also were mixed. Service-learners increased their political awareness, social justice attitudes, and problem solving skills, but their interest in learning about local and national politics, understanding of the impact of social institutions on the individual, and ability to work with others decreased.

In regard to community engagement, again the findings were mixed. While service-learners' preferences for short-term community involvement and desires to make a difference in others' lives increased throughout the semester and their behavioral motives for community involvement increased from the beginning to the middle of the semester, these behavioral motives then decreased from the middle to the end of the semester (Simons \& Cleary, 2005). Finally, service-learners formed positive relationships with service-recipients. Overall, service-learners benefited from their participation.

Research on academic learning also has focused on students' perceptions of the experience. Wittmer (2004) presented the philosophy and mechanics of the community-service or service-learning component of the Daniels College of Business at the University of Denver as well as the results of an evaluation of this component. He noted that the fundamental 
purpose of values-based leadership is "student growth, development, or positive change" (p. 363). The intent is to make students more aware of the needs and problems to which public sector and nonprofit institutions attend and how business can be an active partner in dealing with such needs and problems. The hope is to foster a strong sense of community service and civic engagement among students.

Overall, the results of the evaluation indicated that students had a positive experience with service-learning. In particular, students enjoyed their work in health and human services, education, and recreation organizations as well as activities in the areas of construction, event management/participation, and education/tutoring. Based on these results, Wittmer (2004) believes that community service, as part of the business school curriculum, may increase the future commitment of students to community service.

Madsen (2004) presented the experiences and perceptions of students who had recently completed a service-learning project in an undergraduate compensation and benefits course. She interviewed 12 students, who had chosen a nonprofit organization (community partner) from a list that she had provided and who completed the service-learning project, which included job analysis and job evaluations for two or three positions within each organization.

Madsen (2004) thought that richest understanding could be obtained by analyzing the data in terms of feelings before, during, and after the project, which would enable a view of the evolution of students' feelings. She found that most students started out with hesitation and uncertainty, although some were excited, but that all finished the project with positive feelings about their accomplishments and about themselves. She noted that these responses were supportive of past research on service-learning in other courses and supported prior research that showed that students have similar perceptions of and feelings about service-learning experiences across courses, departments, schools, and colleges. In terms of motivation, Madsen found that all students felt that 
they were more motivated to do better on this assignment than they were on others. Again, this finding was in keeping with that of past research. Madsen also suggested that students' motivation to do well in service-learning projects could be enhanced through service-learning assignments that are well designed.

Using the data from the Madsen (2004) study, Madsen and Turnbull (2006) presented the experiences and perceptions of students who had recently completed a service-learning project in an undergraduate compensation and benefits course. The service-learning project consisted of job analyses and evaluations for the students' chosen nonprofit organizations, and students were required to produce an initial proposal, final report, reflective journal, oral report to the class, and presentation to the site contact. Their focus was students' perceptions of (a) pedagogical differences, (b) learning, (c) personal benefits, and (d) challenges and problems.

In regard to pedagogical differences, students felt that their learning was enhanced by the service-learning project because they could see that what they learned in class works in the real world. Students noted that they could retain course materials better and felt that they learned more, overall. The results for learning were divided into two categories: direct learning (specific course content) and indirect learning (business-related competencies, skills, knowledge, and abilities), both of which were cited by students. In terms of these personal benefits, students cited feeling more confident, having a sense of accomplishing something meaningful, and learning to feel comfortable going into an organization. Finally, in regard to challenges and problems, the largest number of student phrases concerned the challenges of dealing with service-learning as a team project, particularly coordinating everyone's efforts. Students also cited difficulties with community partners, e.g., not feeling appreciated, and the challenge of the many uncertainties that were part of the project. Overall, however, the students felt that the benefits of the experience outweighed the challenges and problems (Madsen \& Turnbull, 2006). 
Hardie, Koster, and Zahaf (2011) conducted an exploratory study designed to (a) determine the impact of community service-learning (CSL) on students' learning experience by comparing the ranking of the students' perceptions of their CSL experience to the rankings of grades received on the CSL component of the course; (b) explore differentiating and discriminating factors between business and non-business students and, hence, determine the importance of the context to CSL courses; and (c) classify and profile CSL students with regard to their performance. Participants included students who were third- or fourth-year business or non-business students and who were enrolled in a CSL course in which the CSL component was at least $20 \%$ of the final grade. Additionally, the selected CSL courses had differing percentages allocated to CSL evaluation.

A researcher-developed structured questionnaire, based on the SErvice LEarning Benefit (SELEB) scale developed by Toncar, Reid, Burns, Anderson, and Nguyen (2006), was used to collect the data. The results confirmed that the business versus non-business courses were different in nature. The different experiences provided a source of differentiation between business and non-business students in terms of "personal growth, leadership and communication skills, critical thinking, gaining trust of others, [and] connecting theory to practice" (p. 171). Although the CSL component-weighing scheme was different for the different courses, the weight was not critical in the students' learning. Business students scored higher than did non-business students on the items of "the course is more demanding, more challenging, and more intellectually stimulating” (p. 171). Overall CSL improved students' learning experience, and "all students perceived CSL courses as being more structured and more exciting than standard course[s]" (p. 171).

Researchers also have evaluated the impact of academic servicelearning projects on the clients. Walsh (2002) stated that, while collective service-learning can be a transformative experience for students, they also provide "insights that may be genuinely helpful to business opera- 
tions" (p. 233). He explained that the collaborative, team-oriented, creative, consultative, and hands-on processes of student-learning experiences are what make them meaningful. Through these processes, students apply what they learn, provide insights, and engage in research that can create a new focus and intensity. Walsh cited several student research projects that gathered data used for projects to benefit the school and its students as well as projects that were conducted on behalf of off-campus businesses and nonprofit entities. He noted that, over a 12-year period, students at a small rural college in upstate New York have engaged in service-learning experiences that have resulted in local appreciation and international awards.

Crutsinger, Pookulangara, Tran, and Duncan (2004) presented their experiences with implementing a service-learning project in a retail organization and included a discussion of project development, implementation, and evaluation. The service-learning project was implemented in an advanced merchandising applications course; the course objectives were to (a) engage students' critical thinking skills through the application of theories and principles to an industry situation; (b) develop the interpersonal skills required to express thoughts and feelings in the context of group projects, and (c) use a variety of perspectives to solve retail problems. The company's feedback was positive, in terms of both increased product knowledge and job performance. Students felt that they had derived benefits in four areas: teamwork, personal responsibility, problem solving, and networking. Finally, faculty saw student growth in research skills, interpersonal communication, and initiative and felt that the course objectives had been achieved.

\section{Summary}

The literature demonstrates the value of the constructivist classroom and of academic service-learning. Specifically, the constructivist classroom method of teaching enhances student learning and is favorably received by students (Lattuca, 2006; Milbrandt et al., 2004; Travis \& Lord, 2004). Further, the work of Dewey (1938), as developed by Kolb (1984), 
indicates that quality experiences facilitate the learning process. One such experience, academic service-learning, can benefit both students and the community. Bush-Bacelis (1998) found that academic servicelearning can assist students in learning abstract concepts, while Papamarcos (2002) noted additional benefits, including fostering personal development and a sense of responsibility. Barr (2010) stated that academic service-learning can enhance career development and, along with Buff (2011), identified successful learning outcomes in courses that provide an analytic component. Simmons and Cleary (2005), however, had mixed results with regard to academic learning and community engagement but nevertheless felt that service learners benefited from their projects. Wittmer (2004), Madsen (2004), and Hardie et al. (2011) found that students perceive academic service-learning as supportive of the community. Finally, Walsh (2002) and Crutsinger et al. (2004) noted that the community organizations involved in academic service-learning projects perceive the project as valuable.

\section{Purpose and Research Questions}

Although the literature has shown the benefits of the constructivist classroom approach for students and of academic service-learning for students and the community, it would be valuable to determine whether the benefits of academic service-learning could be sustained by the use of the constructivist classroom approach. Thus, the purpose of this study is to determine the perceived effects of employing a constructivist classroom approach on academic service-learning from the perspectives of students and the community-client. To this end, the following research questions guide the study:

Research Question 1: To what extent did the students perceive the academic service-learning project as valuable to the community?

Research Question 2: To what extent did the students perceive the academic service-learning approach as a valuable instructional method? 
Research Question 3: To what extent did the community-client perceive the academic service-learning project as valuable?

\section{Context of the Study}

The 15-week capstone Strategic Management course emphasizes the use of knowledge and skills developed in prerequisite courses to conduct problem analysis and decision-making in the process of strategy formulation in a firm. As the capstone, students in this course are essentially ready to graduate, having completed almost all coursework for their respective degree requirements, such as marketing, management, accounting, and finance. The general goals of the course are to introduce students to the methods to develop a strategic plan for a variety of organizational types, understand how to implement a strategic plan, and, as a result, gain better written oral and communication skills. These general goals are achieved through attention to strategy concepts, such as internal analysis, external analysis, functional and competitive strategies, corporate strategies, international strategies, ethical frameworks for strategy development, and strategic deployment.

Enrolled in the spring 2013 course were 39 traditional, full-time college students (28 males and 11 females). This course section met weekly for 2.5 hours. The course was administered as a constructivist classroom with out-of-class assigned readings, discussion boards, and video, while in-class work focused on aspects of an academic service-learning project. A strategic management text also was used.

Students were asked to self-select into six teams. Each team was to have at least one student who majored in management, one in finance, one in marketing, and one in accounting. Several teams had more than one individual representing a major. This cross-functional team criterion mimicked a strategic management team in industry.

The teams worked independently to develop a feasible strategic plan, including implementation plans, for the non-profit organization (commu- 
nity client) chosen by the professor for the semester. The non-profit was a local animal humane society, administered entirely by volunteers.

Each team was required to develop its own vision and mission, contract for work, and weekly point-demerit program. The vision and mission were developed in class after students conducted out-of-class work on vision and mission theory development. After formulating their visions and missions, the teams then worked on developing their contracts and payment schedules.

The contracts specified the roles and responsibilities of the team members, with detailed information on expectations for class attendance and out-of-class work, including team meeting attendance and conduct, discussion board participation, project deliverable development, decision-making criteria, team member dismissal criteria, and payment plan agreement.

Each week, each team member began with the potential to receive 50 points. Based on the team contract and the member's participation in the team for that week, the team as a whole would determine how many of the 50 points would be allotted to each team member. This allocation was then submitted to the professor each week, within 24 hours of the in-class session, according to the contract that they had developed. For example, if the contract indicated a member would be docked 25 points for missing a class, then the paycheck for that team member would be no more than 25 points for that week. Each team submitted a single point allotment document to the professor that contained a list of all team members and the allotment for each member. If the paycheck was not received in time, no allotment was made to any member of the team.

Team member dismissal criteria developed by each team allowed for a team to "fire" one of its members. Firings could occur only after the team attempted a documented performance improvement plan with the member. Firings required the professor's final approval. In the event of a firing, the dismissed member had to complete the project by him or herself, but would not be allowed to present the final project and, 
thus, sacrificed presentation points. No student was fired during the course of this study.

For the kick-off event, the entire class met with the community client on its premises for a tour of the facility and to learn more about the challenges faced by the client. At around mid-term, the community client was invited to bring several of its members to the class to meet independently with teams to answer the team's questions and to provide more insight into its needs and operation. Between these face-to-face whole class events, teams interfaced independently with the community client for strategy formulation and implementation planning as guided by the weekly assigned concept.

Each week, students were asked to read chapters from the text and review video, as relevant, outside of normal class time. To further enhance learning, weekly discussion questions were posted by the professor in an electronic discussion forum. The weekly discussion questions related to the readings and out-of-class assignments and were written in terms of the community client. To achieve a deeper understanding of the material, students were required to reply to two initial posts and to post one meaningful contribution to the discussion prompt. This discussion forum further allowed the professor to monitor understanding of the material and, where misunderstanding was noted, post clarifications to the theory.

During class time, the students met as a whole class for approximately 30 minutes. During this time, the professor briefly reviewed the theoretical content assigned and elaborated on the discussion forum. The students then broke into their teams for the remainder of the class to work on the practical application of the theory in terms of the academic servicelearning project. For example, if the lesson content was related to internal analysis, then the students would break into their teams and conduct an internal analysis for the community client, based on the theory provided and their interaction with the community client. The professor would facilitate the work by sitting with each team and discussing their work, challenges, and outcomes. Students would provide evidence of work, 
such as a hand-written, roughed-out internal analysis, prior to leaving the class.

At the end of the semester, each team presented its strategy and implementation plan to the community client. The presentation was augmented with a written paper on the formulation process. The community client then allotted "payment" to each team, based on merit of work.

\section{Research Design ANd Methodology}

This exploratory research employed a mixed-methods approach. Quantitative data consisted of responses to Likert-scaled items, while qualitative data comprised responses to open-ended questions. Three instruments were used and are described in detail under Instrumentation.

Near the conclusion of the semester, the university provided students with an online course evaluation tool, which is part of the university's course evaluation protocol. This questionnaire was administered electronically, without the need for student self-identification, which ensured confidentiality, and the student was allowed to opt out of its completion. Further, because the university administered the questionnaire, only summary results are provided to the professor and only after final grades are entered. There were no incentives offered by the professor to students to complete the survey; the students were simply reminded by the professor that the survey was available for completion and that the results are important to the professor and to the university for the purpose of continual improvement.

For the purpose of this study, the professor selected specific questions from this questionnaire. Specifically, the questions selected were those determined to be most closely linked to the students' perceptions of the value of the instructional method. The questions selected comprise the Student Perceptions of the Course (SPOC; Appendix A) instrument. The responses to this survey tool were used to address Research Question 2: 
To what extent did the students perceive the academic service-learning approach as a valuable instructional method?

After the conclusion of the semester, the professor developed another instrument to determine the extent to which students believed that the academic service-learning project was of value to the community (Student Perceptions of Community Service [SPCS]; Appendix B). Student responses to SPCS were used to address Research Question 1: To what extent did the students perceive the academic service-learning project as valuable to the community?

The SPCS instrument was administered through the online survey tool Qualtrics. ${ }^{\mathrm{TM}}$ This tool gathers data in an anonymous fashion, with the administrator of the survey responsible for the data analysis. The professor emailed the SPCS web link to the students, and the accompanying text included the purpose of the survey and its voluntary nature as well as ensured confidentiality.

The professor also developed a third instrument to determine the extent to which the community client perceived the academic service-learning project as valuable (Community Client Perceptions of Service-Learning Project Value [CPSL]; Appendix C). The responses to this instrument were used to address Research Question 3: To what extent did the community client perceive the academic service-learning project as valuable?

As with the SPCS instrument, the CPSL was administered through Qualtrics. ${ }^{\mathrm{TM}}$ The professor emailed the survey link to the president of the community organization that served as the client. The text accompanying the link indicated that the purpose of the instrument was to gather data on the perceptions of the value of the project. The text also indicated that completion was voluntary. Because a limited number of individuals interfaced with the students, the president was asked to compile these individuals' answers to the questions and then to complete the instrument such that it represented the consensus of the individuals involved. In this way, individual identities also would be protected. 


\section{Instrumentation}

As noted, three instruments were used in this study. The SPCS was used to understand student perceptions of community service, while the SPOC was used to determine students' perceptions of the course. A third instrument, the CPSL, was used to evaluate the community client perceptions of the project's value.

\section{Student Perceptions of Community Service (SPCS)}

The SPCS was administered to students to determine their perceptions of the academic service-learning project as valuable to the community (Appendix B). The SPCS contains five items, stated in a positive format, answered on a 5 -point Likert scale $(1=$ strongly disagree to $5=$ strongly agree). The response rate for this survey instrument was $46 \%$ (18 of 39 students). Because responses are available for each student, means and standard deviations can be determined.

\section{Student Perceptions of the Course (SPOC)}

The SPOC was administered to the students by the university as part of routine course evaluation (Appendix A). SPOC contains 25 items that concern engagement, course structure, course implementation, and instructor performance. Of these 25 items, as noted, 10, which have an emphasis on student engagement and course structure, were selected by the professor as relevant to the purpose of this study. Of these items, 8 were presented as Likert-scaled, with the response scale varying according to the item. In some cases, the scale anchors were "strongly agree" to "strongly disagree," while other anchors were "poor" to "excellent." Except for one item for which a 4-point Likert scale was used, all other items used a 5-point scale. The last two items were open-ended questions.

The response rate for this survey was $30.8 \%$ (12 of 39 students). The university provides the results of its course evaluation survey in a summary format, with reported percentages and means for each question in terms of the scale used. The summary also includes comment areas, and 
all comments are provided. Because the results are summarized, it is not possible to calculate means or standard deviations across respondents.

\section{Community Client Perceptions of Service-Learning Project Value (CPSL)}

The CPSL was administered to the community client to determine the client's perception of the project as valuable to its organization (Appendix C). The CPSL contains 10 items, stated in a positive format and answered on a 5 -point Likert scale $(1=$ strongly disagree to $5=$ strongly agree). This instrument was administered to a single organization, and because the responses represent a consensus of perceptions, it is not possible to calculate means and standard deviations across respondents.

\section{Data Analysis}

This exploratory study utilized both quantitative and qualitative data. Each research question was addressed using either quantitative or qualitative data or a combination thereof. Additionally, comments, where available, were summarized to determine the general feel of the comments, that is, as negative or positive in connotation.

Research Question 1: To what extent did the students perceive the academic service-learning project as valuable to the community? This research question was addressed by responses to the SPCS instrument. As noted, due to the mechanism of administration, individual survey responses were known, which allowed for the calculation of means and standard deviations for each item.

The academic service-learning project would be considered a valuable contribution to the community if the overall mean for the survey exhibited a value between 4 and 5 (agree or strongly agree) with a standard deviation of less than 1.0. An additional consideration would be in terms of each item's mean and standard deviation across all respondents exhibited 
mean values between 4 and 5 (agree or strongly agree), and standard deviations of less than 1.0.

Research Question 2: To what extent did the students perceive the academic service-learning approach as a valuable instructional method? This research question was addressed by responses to the SPOC instrument. As noted, the data used to address this research question were selected from the university-administered course evaluation instrument, and the university provides the professor with frequency summary data as well as means; as such, it is not possible to determine standard deviations. These summary data include Likert-scored responses as well as comments that are either positive or negative.

The academic service-learning project would be considered a valuable instructional method if the means for items $2-8$ exhibited values between 4 and 5 (agree or strongly agree) and the mean for item 1 exhibited values between 3 and 4, as the item 1 Likert scale evaluates responses along a 1 - 4 continuum, while the remaining items are evaluated on a $1-$ 5 continuum. An additional consideration would be if the comments provided by the students conveyed generally positive feelings concerning the course.

Research Question 3: To what extent did the community-client perceive the academic service-learning project as valuable? This research question was addressed by responses to the CPSL instrument. As noted, due to the mechanism of administration, individual responses were not known, and, as such, means and standard deviations could not be calculated. An analysis of the extent of agreement with each item could be conducted, and it was possible to calculate the overall mean and standard deviation for the items.

The academic service-learning project would be considered valuable to the community client if the overall mean for the survey items fell between 4 and 5 (agree and strongly agree), with a standard deviation of less than 1.0. 


\section{RESULTS}

Research Question 1: To what extent did the students perceive the academic service-learning project as valuable to the community? This question concerned whether students' perceptions of community service remained positive, as suggested by prior academic service-learning research within the constructivist classroom setting.

The means and standard deviations across all respondents for each SPCS item were determined as were the overall mean and standard deviation, which were 4.33 and 0.47 , respectively. The results for each item are presented in Table 1.

Research Question 2: To what extent did the students perceive the academic service-learning approach as a valuable instructional method in the constructivist classroom? This question concerns whether the students' perceptions of learning remained positive, as suggested by prior academic service-learning research within the constructivist classroom setting.

The mean for each item was calculated. The overall mean for items 2 - 8 was 4.51 (this value excludes the value of the first survey inquiry). The mean for the first inquiry was 3.67. The means for each item are presented in Table 2 .

The responses to the two-open ended questions were all positive. The comments in response to Item 9, "Would you recommend this course to other students? Why or why not?" generated comments describing the course as valuable in its structure to meet learning goals:

"Extremely useful for my major. Gave me real world experience that was invaluable."

"Great class!"

"Learned a lot from this class and loved the organization we were assigned to!" 
"Professor structured this course to fit the way almost all students ACTUALLY LEARN! This course was not the typical, 'Go buy this book and read it and I'll throw a test at you,' but rather to collaborate with your team members, as you will have to in your future careers, research. [You will have to] contribute, teach, and build off of each other [just] as she oversaw what we were doing and asked us questions to guide us in the right direction rather than giving us a test with red ink on it, leaving us with no clue as to why our answer is wrong."

The comments in response to Item 10, "Please provide any additional comments you have regarding this course," were also positive in connotation; additionally, these comments were quite consistent with the responses to Item 9 in terms of course structure:

"This course is necessary to learn how developing business strategies work."

"Because it was hands-on, I was able to learn in a fun way, which makes the material more engaging."

"The way this course is set up will ensure that you truly learn."

"Very fun, engaging class! You actually want to do the work because of the excitement!"

Research Question 3: To what extent did the community-client perceive the academic service-learning project as valuable? This question sought an understanding of whether the community-client's perceptions of project outcomes remained positive, as suggested by prior academic service-learning research.

The responses to each of the CPSL survey inquiries were determined. All (10 of 10) responses consisted of a 5 (strongly agree) rating. 


\section{Discussion}

It appears that the use of the constructivist classroom in conjunction with academic service-learning supports students' positive perceptions of the value of the service-learning project to the community and as an instructional method. Further, it appears the simultaneous use of these two approaches provides a product perceived as valuable to the community client. Thus, the effect of using a constructivist classroom approach with academic service-learning appears to be positive.

The results for the Perceptions of Community Service survey support positive perceptions with regard to community service. This finding is consistent with that of Wittmer (2004) who found that students had a positive experience with community service or service learning. Additionally, Wittmer suggests that such learning allows students to understand the role and importance of community service. The data from this study are in support of that contention.

The results for the Perception of the Course survey reflect positive perceptions with regard to the instructional design of a course using a constructivist classroom approach with academic service-learning. This finding in terms of the constructivist classroom is consistent with those of Travis and Lord (2004), who found that the use of a constructivist classroom leads to greater material understanding, greater active learning, and better student engagement. Additionally, with regard to academic service learning, these positive course perception results are consistent with the work of Madsen (2004), Madsen and Turnbull (2006), and Hardie, Koster, and Zahaf (2011), who all reported higher levels of student motivation with such assignments, greater feelings of learning and retention on behalf of the students, or greater sense of excitement with regard to the course. The finding is not consistent with the work of Simons and Cleary (2005) who reported mixed findings in terms of academic learning. However, the study by Simons and Cleary was much more empirical in nature, and drew conclusions from evaluations 
performed during the course implementation, as was not the case with this current study.

The project was perceived as successful and valuable to the community-client, as derived from the results of the Perceptions of ServiceLearning Academic Project Value survey. Such a perception is consistent with the findings of both Walsh (2002) and Crutsinger et al. (2004). Both of these studies found that service-learning projects make genuine contributions to businesses, as reported by both the community-client as well as in terms of community-at-large.

\section{Limitations of THE STUdy}

This study contained several limitations. First, there was no control for the professor or the community-client. For example, both the professor and the community-client could influence student perceptions of the course. Second, this study was limited to only one section of the capstone course; it is unclear if the results would be reproducible. Finally, these findings might be applicable only to capstone-level courses in which a large degree of academic prerequisites is completed. For example, students taking capstone courses might be more confident in their academic abilities and thus more comfortable with constructivist classroom pedagogy.

\section{RECOMMENDATIONS}

To accommodate the lack of control group, the study should be repeated, with the course work administered by the same instructor using the same community-client but without the constructivist classroom component. The differences in the students' and community-client's perceptions could then be compared and contrasted. In this way, the results would better reflect the constructivist classroom component, accommodating the influences of the professor and the community-client have on the student perceptions. 
To evaluate the reproducibility of the findings in the capstone course, the study could be repeated. This repeated study could be done in conjunction with the prior recommendation for control groups.

Lastly, to evaluate the application of these findings to lower-level courses, repeated studies could occur using a variety of courses, both at the capstone and prerequisite course level. An analysis could then be done to compare perceptions among course levels, as well as among different majors.

\section{REFERENCES}

Alesandrini, K., \& Larson, L. (2010). Teachers bridge to constructivism. The Clearing House: A Journal of Educational Strategies, Issues and Ideas, 75(3), 118-121. doi.org/10.1080/00098650209599249

Barr, J. (2010). The service-learning experience in a marketing research course: A model for assessing student outcomes. International fournal of Education Research, 5(2), 85-93.

Buff, C. L. (2011). Learning and mission in action: Implementing problem based service learning in the consumer behavior classroom. International fournal of Business Research, 11(5), 123-130.

Bush-Bacelis, J. L. (1998). Innovative pedagogy: Academic service-learning for business communication. Business Communication Quarterly, 61(3), 20-34. doi.org/10.1177/108056999806100303

Crutsinger, C. A., Pookulangara, S. Tran, G., \& Duncan, K. (2004). Collaborative service learning: A winning proposition for industry and education. Fournal of Family and Consumer Sciences, 96(3), 46-52.

Dewey, J. (1897). My pedagogical creed. School fournal, 54, 77-80. Retrieved from http://dewey.pragmatism.org/creed.htm

Dewey, J. (1938). Experience and education. New York, NY: Collier Books.

Hardie, T., Koster, R., \& Zahaf, M. (2011). Assessing the impacts of community service learning on business and non-business student perceptions and grades. Review of Business Research, 11(1), 163-172. 
Kolb, D. (1984). Experiential learning: Experience as the source of learning and development. Upper Saddle River, NJ: Prentice Hall.

Lattuca, L. R. (2006). The constructivist pedagogy we're looking for. Journal \& Mass Communication Educator, 60(4), 354-458. doi.org/10.1177/107769580506000404

Madsen, S. R. (2004). Academic service learning in human resource management education. Fournal of Education for Business, 79(6), 327-332. doi.org/10.3200/JOEB.79.6.328-332

Madsen, S. R., \& Turnbull, O. (2006). Academic service learning experiences of compensation and benefit course students. Fournal of Management Education, 30(5), 724-742. doi.org/10.1177/1052562905283710

Milbrandt, M. K., Felts, J., Richards, B., \& Abghari, N. (2004). Teaching-tolearn: A constructivist approach to shared responsibility. Art Education, 57(5), 19-24, 33.

Papamarcos, S. D. (2002, Spring). The "next wave" in service-learning: Integrative, team-based engagements with structural objectives. Review of Business, 31-38.

Simons, L., \& Cleary, B. (2005). Student and community perceptions of the "value added" for service-learners. Fournal of Experiential Education, 28(2), 164-188. doi.org/10.1177/105382590502800208

Toncar, M. F., Reid, J. S., Burns, D. J., Anderson, C. E., \& Nguyen, H. P. (2006). Uniform assessment of the benefits of service learning: The development, evaluation, and implementation of the SELEB scale. Journal of Marketing Theory and Practice, 14(3), 223-238. doi.org/10.2753/MTP1069-6679140304

Travis, H., \& Lord, T. (2004). Traditional and constructivist teaching techniques. Journal of College Science Teaching, 34(3), 12-18.

Walsh, S. M. (2002). Collective service learning experiences uncover both personal and interactive student potentialities: A case study within an academic setting. Journal of Nonprofit \& Public Sector Marketing, 10(2), 231-241. doi.org/10.1300/J054v10n02_13

Wittmer, D. P. (2004). Business and community: Integrating service learning in graduate business education. Fournal of Business Ethics, 51, 359-371. doi.org/10.1023/B:BUSI.0000032514.05498.2b 


\section{Web Appendix}

A web appendix for this paper is available at:

http://dx.doi.org/10.15239/j.brcacadjb.2015.04.01.wa03

\section{Citation Information}

Walters, Lisa M. "Perceptions of the Effects of a Constructivist Classroom Approach on Academic Service-Learning: An Exploratory Study." The BRC Academy Journal of Business 5, no. 1 (2015): 35-65. http:// dx.doi.org/10.15239/j.brcacadjb.2015.04.01.ja03 